\title{
Visualizing the Knowledge Domain of Project Governance: A Scientometric Review
}

\author{
Zhao Zhai $\mathbb{D}^{1},{ }^{1}$ Ming Shan $\mathbb{D}^{2},{ }^{2}$ Amos Darko $\left(\mathbb{D},{ }^{3}\right.$ and Yun Le ${ }^{4}$ \\ ${ }^{1}$ School of Traffic \& Transportation Engineering, \\ Engineering Research Center of Catastrophic Prophylaxis and Treatment of Road \& Traffic Safety of Ministry of Education, \\ Changsha University of Science \& Technology, Changsha 410114, China \\ ${ }^{2}$ School of Civil Engineering, Central South University, Changsha 410075, China \\ ${ }^{3}$ Department of Building and Real Estate, The Hong Kong Polytechnic University, Hong Kong, China \\ ${ }^{4}$ School of Economics and Management, Research Institute of Complex Engineering \& Management, Tongji University, \\ Shanghai 200092, China
}

Correspondence should be addressed to Ming Shan; ming.shan@csu.edu.cn

Received 19 November 2019; Revised 19 January 2020; Accepted 28 January 2020; Published 19 February 2020

Academic Editor: Heap-Yih (John) Chong

Copyright (c) 2020 Zhao Zhai et al. This is an open access article distributed under the Creative Commons Attribution License, which permits unrestricted use, distribution, and reproduction in any medium, provided the original work is properly cited.

\begin{abstract}
Over the past two decades, project governance has attracted increasing attention from researchers and practitioners worldwide and has become an important research area of project management. However, an inclusive quantitative and systematic analysis of the state-ofthe-art recently available research in this field is still missing. This study attempts to map the global research on project governance through a state-of-the-art review. A total of 285 bibliographic records were retrieved from the Web of Science Core Collection database and analyzed by the visual analytic tool-CiteSpace. The results indicated that there has been an increasing research interest in project governance. The most productive and the most highly cited author in the area of project governance is Müller R., and most of the existing project governance research achievements are from Australia, China, USA, and Norway. By synthetically analyzing the keywords, future research might focus on governance of megaprojects and project success. Additionally, 9 knowledge domains of project governance were identified, including conceptual framework, public projects, governance structure, governance context, megaproject governance, contractual and relational governance, sustainability, portfolio governance, and project success. This study contributes to the body of knowledge by mapping the existing project governance research. It is particularly helpful to new and early-stage researchers who plan to do research on project governance, as it can provide them an overview of project governance research, including key authors, main institutions, hot topics, and knowledge domains. Moreover, the findings from the study are beneficial to industry practitioners as well, as they can help industry practitioners understand the latest development of governance theory and practice and thereby help them locate the best governance strategies for project management.
\end{abstract}

\section{Introduction}

Project governance, a key enabler for successful project delivery, is an important topic in the construction and project management area $[1,2]$. In the project management literature, project governance has been defined as "an oversight function that is aligned with the organization's governance model and provides the project manager and team with structure, processes, decision-making models, and tools for managing the project" [3], or the means of setting, attaining, and monitoring project objectives [4].
Recently, researchers and practitioners have attempted to investigate project governance from different perspectives. Bekker [5] formulated three project governance schools from the perspective of corporate governance, and Müller, et al. [2] distinguished project governance from the perspectives of individual projects and groups of projects. From the central government perspective, Volden and Samset [6] examined how the project governance scheme operated in major projects. Cardenas et al. [7] developed a causal model to help managers choose the right governance actions to guarantee satisfactory project outcomes; while 
Brunet [8] studied project governance in public projects from process processual and practice perspectives.

Although definitions offered for project governance vary, it has been acknowledged that project governance refers not only to management means that facilitate the progress of projects [9], but also to hierarchy, market, or network arrangements applied by the top management to enhance effectiveness and efficiency $[10,11]$. Empirical research studied governance approaches in different industries or project types, such as public projects $[9,12,13]$, software projects [14], and megaprojects [15-17].

Previous researches also include reviews of project governance research. For example, Biesenthal and Wilden [1] conducted a comprehensive review and conceptualized project governance at the project, project management office, and organizational levels. Ahola et al. [18] identified two research streams: project governance as an external approach to any specific project aiming to set standardized rules in alignment with the strategy of the project-based firm; and project governance as internal to a project dealing with interorganizational challenges. Too and Weaver [19] examined existing project governance research and proposed that good project governance should achieve optimal balance between portfolio management, project sponsorship, project management and office and program support and improve project performance. Lappi et al. [20] reported a six-dimensional framework of project governance in agile projects. Derakhshan et al. [21] developed a project governance model adopting a stakeholder approach. Whilst many research have been carried out, a universally recognized understanding of project governance concept is still lacking [22, 23], and themes of project governance remain fragmented $[22,24,25]$. There remains a paucity of evidence on a holistic analysis of project governance research.

Accordingly, the present study used the scientometric technique to capture a holistic analysis of project governance research. The specific objectives of this study are (1) to identify the key contributors (authors, institutions, and countries) to project governance (PG) research; (2) to identify the popular research topics and how these topics evolve over time; (3) to identify major knowledge domains of PG research and to reveal the possible directions for future research. The findings can provide researchers and practitioners with a better understanding of existing PG research and identify the hot topics, frontiers, and knowledge domains in the literature.

\section{Research Method and Data Collection}

This study adopted the scientometric review method because scientometrics has come to prominence in evaluating research performance and revealing the internal structure of scientific fields [26]. Scientometric analysis is "the study of the quantitative aspects of the process of science as a communication system" [27] and could reduce the influence of researchers' subjective opinions on research hotspots and enhance the objectivity and reliability of results [28]. Based on cocitation analysis, scientometrics can help researchers understand the knowledge mapping of scientific fields and trace development frontiers [27, 29]. The flow diagram of selecting and analyzing data is illustrated in Figure 1.

Accordingly, many science mapping techniques have been generated to analyze networks of cocited references based on bibliographic records [27, 29]. Among these, CiteSpace represents a free and popular software, specifically designed for exploring the emerging trends and important changes in various research areas [29]. It takes a set of bibliographic records as its input and delineates the intellectual structure of the knowledge domain through cocitation and pathfinder algorithms [28]. Besides, CiteSpace has been used to analyze relationship networks and summarize characteristics of research in the project management research domain [30-32]. Therefore, in the present study, CiteSpace was chosen as the visual analytic tool to analyze the extant project governance literature.

2.1. Data Collection. The analyzed bibliographic records were retrieved from the Web of Science Core Collection database, including Science Citation Index Expanded (SCIEXPANDED) and Social Sciences Citation Index (SSCI). This is because this database contains most influential and highquality publications covering many research subjects [33]. To eliminate the "information noise," publication styles other than journal articles were excluded. This criterion was similar to those reported by Biesenthal and Wilden [1], de Rezende et al. [30], and Zhao [31]. The search process was as follows.

First, in order to acquire an overview of the PG research, an initial scoping search was ran in the database, with terms "project governance" OR "governance of project*" OR "program governance" OR "portfolio governance" OR "project management governance." The search was conducted in the title, abstract, and keywords of publications. For practical reasons, only publications in English were remained. This process resulted in a total of 205 articles in early January 2020. Among those, almost half of them were published in three highly influential project research journals, which were International Journal of Project Management (50 records), Project Management Journal (19 records), and International Journal of Managing Projects in Business (16 records). The result is consistent with those of previous studies indicating that the main project management journals published most PG studies [18, 22].

Second, in line with the search strategies of Ahola et al. [18] and ul Musawir et al. [22], a search query was conducted in the three key journals again with the term "governance" in the title, abstract, and keywords. The abstracts of resulting articles were read, and articles were excluded if the central topic was not really related to PG research. This phase singled out 183 articles. Overall, the two iterative identification processes resulted in a total of 285 articles published from 2002 to 2019 for further analysis.

2.2. Scientometrics Analysis. The scientometrics analysis followed the procedures presented in the CiteSpace manual [28]. CiteSpace supports author cocitation analysis, document cocitation analysis, and coword analysis by modeling and visualizing networks and maps [28]. In the visualization 


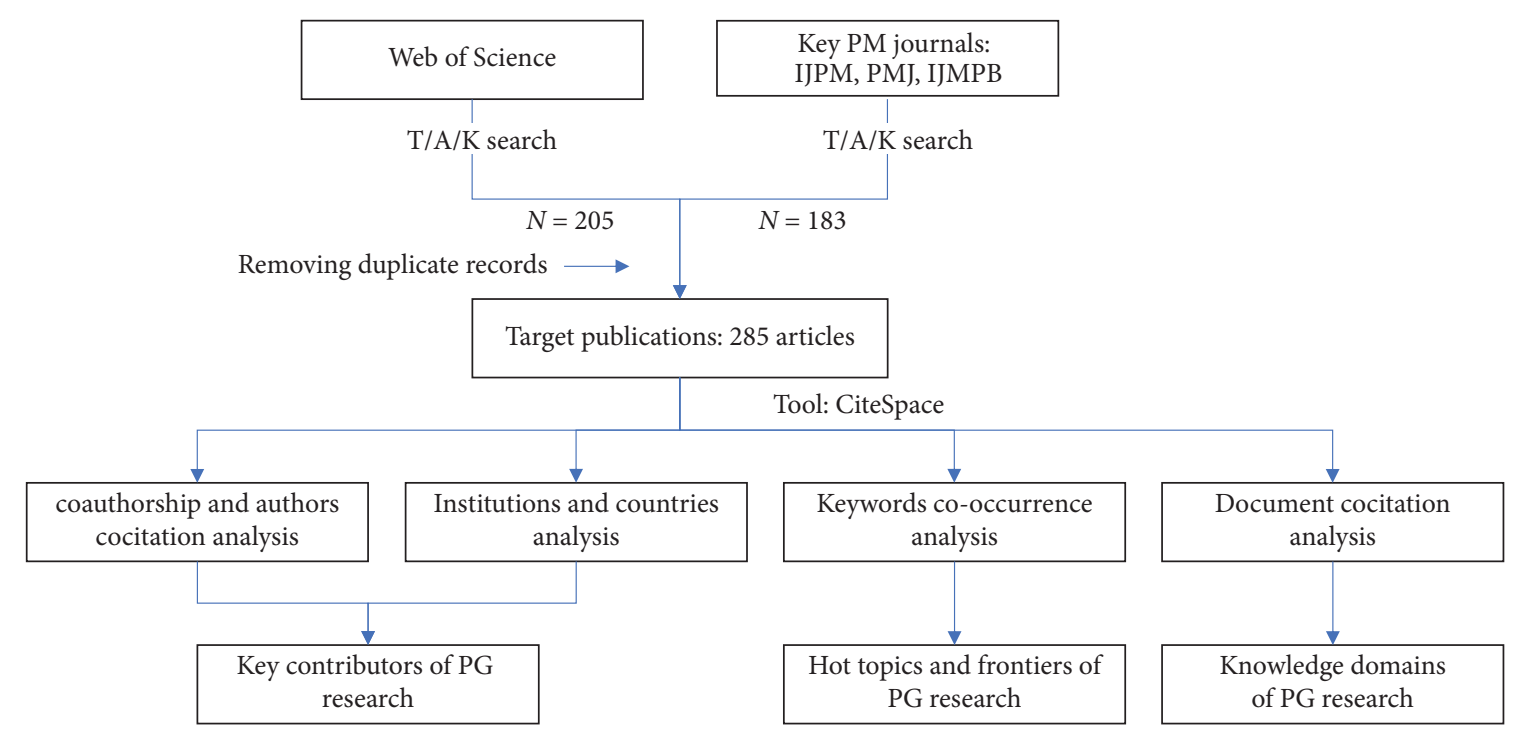

FIGURE 1: Scientometric review search, selection, and analysis breakdown.

knowledge maps, there are nodes and links representing elements (i.e., authors, institutions, and countries) and relationships of collaboration or cocitations. To detect the collaborative research networks in the project governance field, coauthorship analysis was employed. Authors, institutions, and countries were selected as node types to determine the major facets of project governance research. In each case, the links in the map showed scientific collaborations. To reveal the research patterns and trends in the field, keyword co-occurrence and cluster analyses were performed, with the nodes being keywords and references and lines that connected nodes being cocitation links.

Some parameters in CiteSpace should be properly set in accordance with the research objectives. (1) Time scaling value was set to 1 , which means that the entire time interval was divided into several 1-year slices for data processing. (2) In order to form the final networks, node selection criteria, "Top 50 per slide," and "Threshold Interpolation" were followed. "Top 50 per slide" means that the 50 most cited or occurred items from each slide are selected to construct a network. When the number of items were not big enough to present a network, the Threshold Interpolation was used. In Threshold Interpolation setting, there are three parameters: $\mathrm{C}, \mathrm{CC}$, and $\mathrm{CCV}$, which refer to the frequency of occurrence, the frequency of co-occurrence between two nodes, and the rate of co-occurrence between nodes. (3) To control the scope of the network model, the pathfinder was chosen to prune the merged network and eliminate redundant connections. Besides, metrics used in this study were citation burst and betweenness centrality. Citation burst provides evidence that a particular publication is associated with a surge in citations [28]. A node with a high betweenness centrality usually connects two or more large groups of nodes with the node itself in between and can be detected by a purple ring in CiteSpace [28].

Based on keyword co-occurrence analysis, some general prominent research groupings can be identified. But CiteSpace provides more precise ways to identify clusters using the clustering function. Cluster analysis extracts noun phrases from the titles, abstracts, and keywords and converts unstructured text into structured data to detect the latent semantic themes. CiteSpace labels each clusters based on three specialized algorithms-inverse document frequency (TF * IDF), log-likelihood tests (LLR), and mutual information tests (MI). LLR usually gives the best result in terms of the uniqueness and coverage [28]. Thus, in this study, LLR was employed.

To ensure the quality of cluster analysis, two important indicators should be checked to measure the structural properties of the network. The Modularity $Q$ represents the extent to which a network can be separated into multiple components [28]. A high modularity may indicate a wellstructured network, but networks with modularity scores of 1 or very close to 1 may reflect the citing behavior or preferences of a single paper, thus it is less representative [28]. The silhouette value represents the level of uncertainty when interpreting the nature of the cluster, i.e., the homogeneity of a cluster. Its value ranges between -1 and 1 . The closer the value is to 1 , the more consistent the cluster members are. In this study, the cluster labeling is expected to be more straightforward with a silhouette value higher than 0.5 .

\section{Results and Discussion}

3.1. Analysis of Publication Outputs. Figure 2 shows the number of publications in each year during the study period. The number of PG articles increased gradually and fluctuated since 2002. It could be observed that before 2012, the number of publications in this field was relatively small. In 2014, the numbers increased sharply from 13 to 38. It might be a significant year from when PG got increasing attention.

3.1.1. Analysis of Coauthorship Network. The 285 publications were published by 615 authors. Table 1 shows the top 8 most productive authors (authors with more than four 


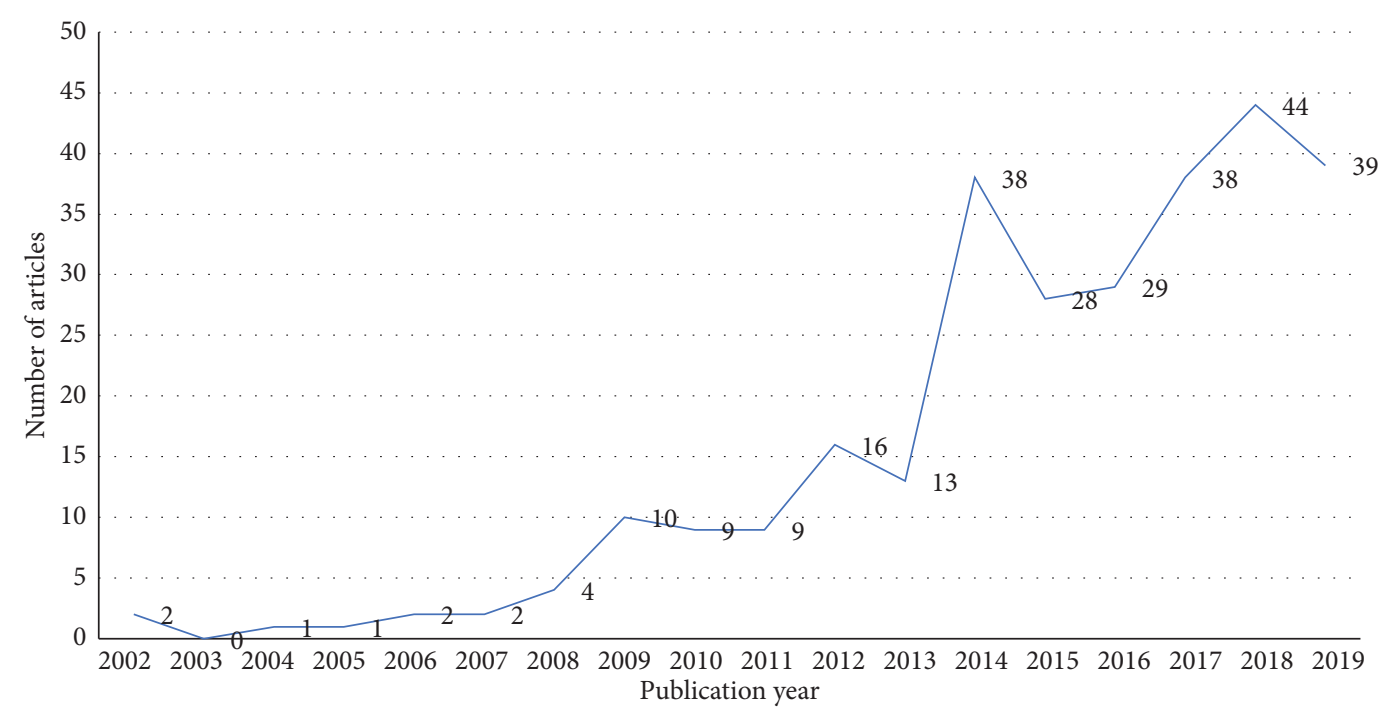

Figure 2: The number of articles on project governance in 2002-2019.

TABLe 1: Top 8 most productive authors in project governance research.

\begin{tabular}{lccc}
\hline Number of papers & Author & Institution & Country \\
\hline 21 & Müller R. & BI Norwegian Business School & Norway \\
9 & Klakegg O. J. & Norwegian University of Science and Technology & Norway \\
8 & Aubry M. & University of Quebec & Canada \\
7 & Ahola T. & Tampere University & Finland \\
7 & Aaltonen K. & University of Oulu & Finland \\
6 & Ruuska I. & Aalto University & China \\
6 & Shao J. T. & China Academy of Social Sciences & UK \\
5 & Locatelli G. & University of Leeds & \\
\hline
\end{tabular}

publications). Among the representative scholars, Ralf Müller (BI Norwegian Business School), Jonny Klakegg (Norwegian University of Science and Technology), and Monique Aubry (University of Quebec) occupied the top three positions.

By applying coauthorship analysis, a group of productive authors who have contributed a large number of publications can be identified. Figure 3 shows a coauthorship network, in which each node represents an author, node size represents the number of publications, and links between nodes denote collaborations among the authors. The colors of links, e.g., blue, green, yellow, and orange, correspond to different years from 2002 to 2019. In terms of the collaboration, there are several closed-loop circuits. For example, the closest connections exist between Ralf Müller, Jingting Shao, Sofia Pemsel, and Monique Aubry. Similarly, strong cooperative relationship can be found between Jonny Klakegg, Terry Williams, and Asmamaw Tadege Shiferaw. In addition, research communities can be identified, in which many authors worked with one highly productive author. For example, Inkeri Ruuska is the central author of a research community, consisting of Karlos Artto, Giorgio Locatelli, and Tuomas Ahola.

3.1.2. Analysis of Institutions and Countries Network. Figure 4 shows the collaborations among countries and institutions. The 285 articles originated from 45 countries/regions.

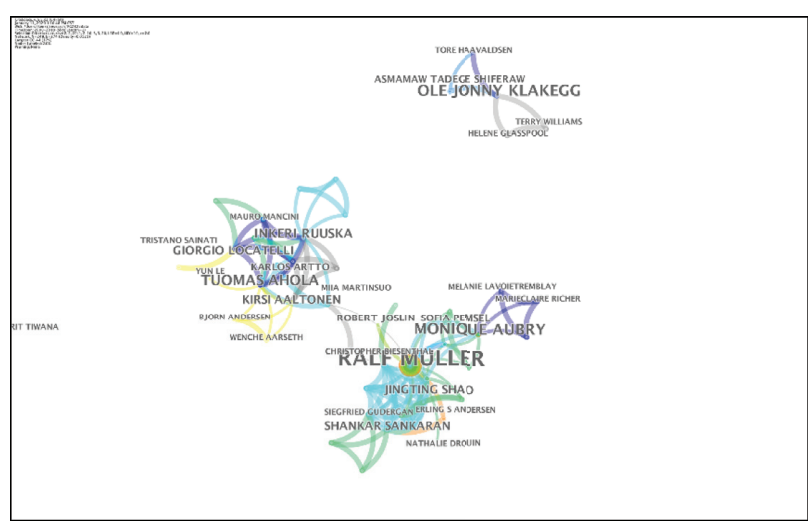

FIGURE 3: Coauthorship network of authors in project governance research.

Table 2 shows that Australia, China, USA, and Norway have made major contributions to project governance research. And institutions, such as BI Norwegian Business School, Norwegian University of Science and Technology, University of Technology Sydney, Tongji University, University of Quebec, and Aalto University, can be seen as the publication centers for PG research around the world. Regarding international collaborations, researchers from Norway have widely collaborated with those from the UK and China. 


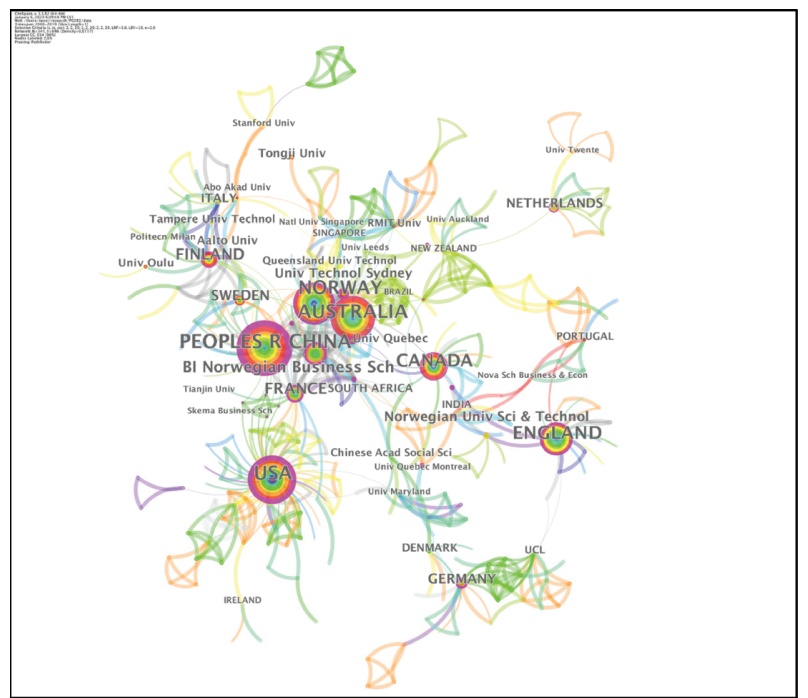

FIGURE 4: Network of countries/regions and institutions in project governance research.

Additionally, the nodes with high betweenness centrality are identified and highlighted by purple rings in Figure 4. Countries/regions such as China (centrality $=0.8$ ), USA $($ centrality $=0.63)$, South Africa (centrality $=0.37)$, France $($ centrality $=0.29)$, and Norway $($ centrality $=0.26)$ and institutions such as University of Technology Sydney (centrality $=0.38$ ), University of Quebec (centrality $=0.28$ ), Tsinghua University (centrality $=0.26$ ), BI Norwegian Business School (centrality $=0.24$ ), and University of Quebec Montreal (centrality $=0.24$ ) occupied key positions in the network and played important roles in connecting research between countries and institutions.

3.1.3. Analysis of Keyword Co-Occurrence. Keywords of an article provide core information about the research conducted, and a knowledge map of keyword co-occurrence reflects the development of research topics [31, 33]. The keywords derived from the WOS database include "Author Keywords," which are supplied by authors, and "Keywords Plus," which are identified by the journals. Generating a keyword co-occurrence map resulted in 147 nodes and 441 links, as shown in Figure 5.

The node size represents the frequency with which a keyword occurred. Besides keywords such as "project governance," "management," "governance," and "project management," the top keywords were "performance" $($ frequency $=54)$, "organization" (frequency $=38$ ), "innovation" (frequency $=30)$, "trust" (frequency $=28$ ), "success" (frequency $=24)$, "impact" (frequency $=24)$, "megaprojects" $($ frequency $=21)$, and "knowledge" (frequency $=20)$. In addition, some keywords received relatively high betweenness centrality scores. Such keywords include "trust" (centrality $=0.34)$, "knowledge" (centrality $=0.29)$, "system" (centrality $=0.26)$, “success" (centrality $=0.19)$, "megaprojects" $($ centrality $=0.16)$, and "innovation" (centrality $=0.16)$. They connected different research topics and significantly influenced the development of project governance research.
To clarify the development path, Figure 6 presents a timeline of project governance research according to the snapshots taken every year. In Figure 6, locations of nodes show the years in which the keywords first appeared. The colors of links show the time of coappearance of two keywords. Relationships among hot topics can be identified in the map. For example, studies regarding performance are primarily associated with topics such as megaprojects, infrastructure, and success. Major focuses of project governance research evolved between 2006 and 2019. For example, studies published in 2009 mainly focused on the knowledge, organization, and performance, whereas in 2013, researchers emphasized research on innovation and trust. In 2014, research focused on construction project and governance framework, and then it shifted to impact and megaprojects in the following two years. From 2017, focus on stakeholder, cooperation, and contractual/relational governance mechanisms appeared. By contrast, no new hot topics of research emerged in 2007, 2008, or 2011.

Time zone analysis gives insights into evolution of hot topics in PG research, but it is unable to find out the frontiers. The frontier areas can be detected based on the variation tendency of word frequency. In Figure 5, eleven keywords in red were found to have citation bursts: "governance" (burst strength $=7.95$, burst from 2006 to 2013), "firm" (4.25, 2012-2014), "project success" (3.81, 2015-2016), "project management"(3.36, 2009-2011), “project governance"(3.22, 2009-2014), “strategy"(2.52, 2012-2014), “perspective"(2.47, 2014-2015), “system"(2.30, 2015-2016), "infrastructure project”(2.01, 2017-2019), “innovation"(2.01, 2013-2014), and "risk"(1.96, 2016-2017). This indicated that these keywords were the hot topics in project governance research in the corresponding years.

As "infrastructure project" or megaprojects and "project success" got the citation bursts in the past four years, as well as high frequency and high betweenness, there is a strong possibility that they would continue to be the key issues in project governance research in the near future. Achieving success has always been one important function of project governance, and it is increasingly being stated [34, 35]. Project governance in megaprojects focus on policy making [15], managing stakeholders [16], and top management $[17,36]$. This result relates to Flyvbjerg [37], who have argued that reform in managing megaprojects is emerging.

\subsection{Analysis of Cited References}

3.2.1. Analysis of Journals Cocitation. Besides the three key journals (IJPM, PMJ, and IJMPB), Journal of Management in Engineering (seven articles), Journal of Construction Engineering and Management (five articles), and Journal of Management Information Systems (four articles) occupied the top positions. To detect the most significant cited journals that together constitute the knowledge domain of PG research, a journal cocitation network was generated, as shown in Figure 7. It indicates the most significant cited journals by the 285 articles with 194 nodes and 351 links. According to cocitation frequency, the top eight most 
TABLE 2: Records ranked by countries and institutions.

\begin{tabular}{lccccc}
\hline Country & Count & Percentage (\%) & Institution & Count & Percentage (\%) \\
\hline Australia & 49 & 17.19 & BI Norwegian Business School & 21 & 7.37 \\
Peoples R china & 48 & 16.84 & Norwegian University of Science Technology & 13 & 4.56 \\
USA & 46 & 16.14 & University of Technology Sydney & 12 & 9 \\
Norway & 43 & 15.09 & Tongji University & 8 & 3.21 \\
England & 37 & 12.98 & University of Quebec & 2.81 \\
Canada & 31 & 10.88 & Aalto University & 7 & 2.81 \\
Finland & 21 & 7.37 & University of Oulu & 2.46 \\
France & 20 & 7.02 & Tampere University of Technology & 2.46 \\
Canada & 12 & 6.15 & Queensland University of Technology & 5 & 2.56 \\
\hline
\end{tabular}

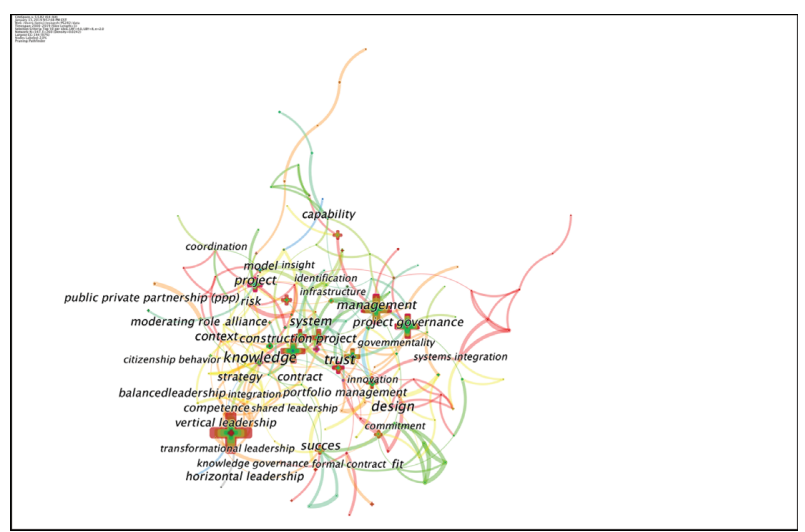

FIGURE 5: Network of co-occurring keywords in project governance research.

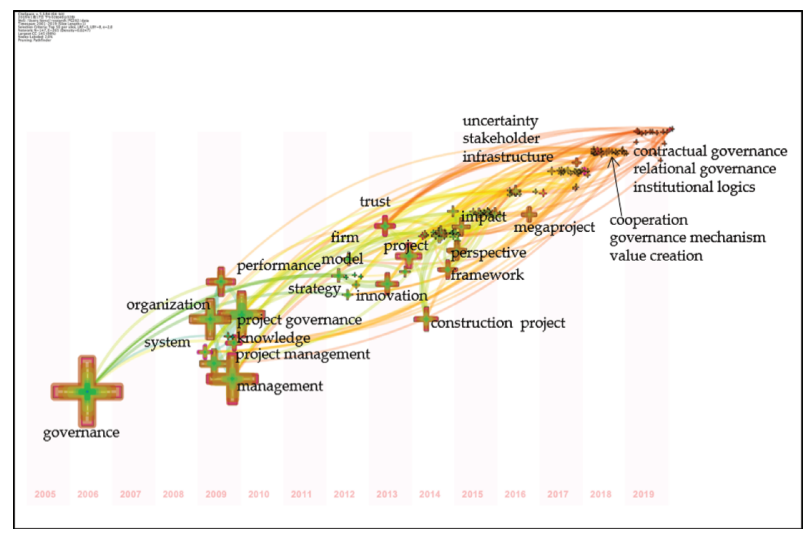

FIGURE 6: Time zone analysis of hot research topics according to the co-occurrence of keywords (modified from the original visualization in CiteSpace).

influential journals were International Journal of Project Management (frequency $=210$ ), Project Management Journal (frequency=168), Academy of Management Review (frequency=137), Academy of Management Journal (frequency $=99$ ), International journal of Managing Projects in Business (frequency=98), Organization Science (frequency $=97$ ), Strategic Management Journal (frequency $=87$ ), and Organization Studies (frequency $=86$ ). The three key journals showing in the top list indicate that the journals with more contributions to PG research also attracted more citations. Others are general management

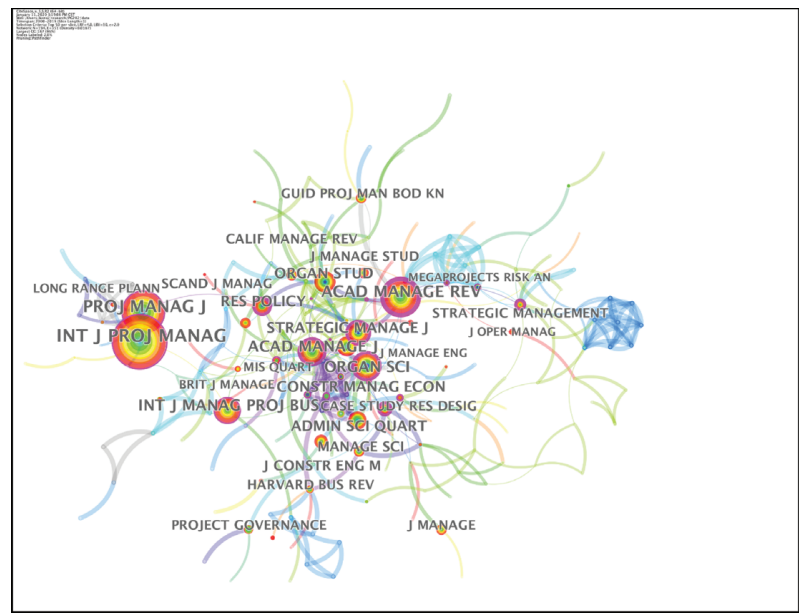

FIgURE 7: Network of journal cocitation.

journals and organization research journals; this reflects the main theoretical origins of project governance.

In Figure 7, the nodes with high betweenness centrality indicate that journals such as Academy of Management Review (centrality $=0.42$ ), Organization Science (centrality $=0.39)$, Construction and Management Economics $($ centrality $=0.26)$, Strategic Management Journal (centrality $=0.23$ ), and Academy of Management Journal (centrality $=0.22$ ) represent major intellectual turning points and act as bridges linking journals in different phases. Additionally, bursts representing notable increases in those publications over a short period were found in 14 journals, shown in Figure 8. For example, The Handbook of ProjectBased Management had the strongest citation burst in the period of 2014 to 2015 with a strength of 5.57. In the past three years (2017-2019), articles published in the Engineering Project Organization Journal (burst strength $=3.41$ ) and Management Decision (burst strength $=3.63$ ) received strong citations. Therefore, these two journals are worth following.

3.2.2. Analysis of Authors Cocitation. Author cocitation analysis can identify the relationships among authors whose publications are cited in the same articles and analyze the evolution of research communities. Figure 9 presents the author cocitation network, containing 255 nodes and 865 links. The node size reflects the number of cocitations of each 


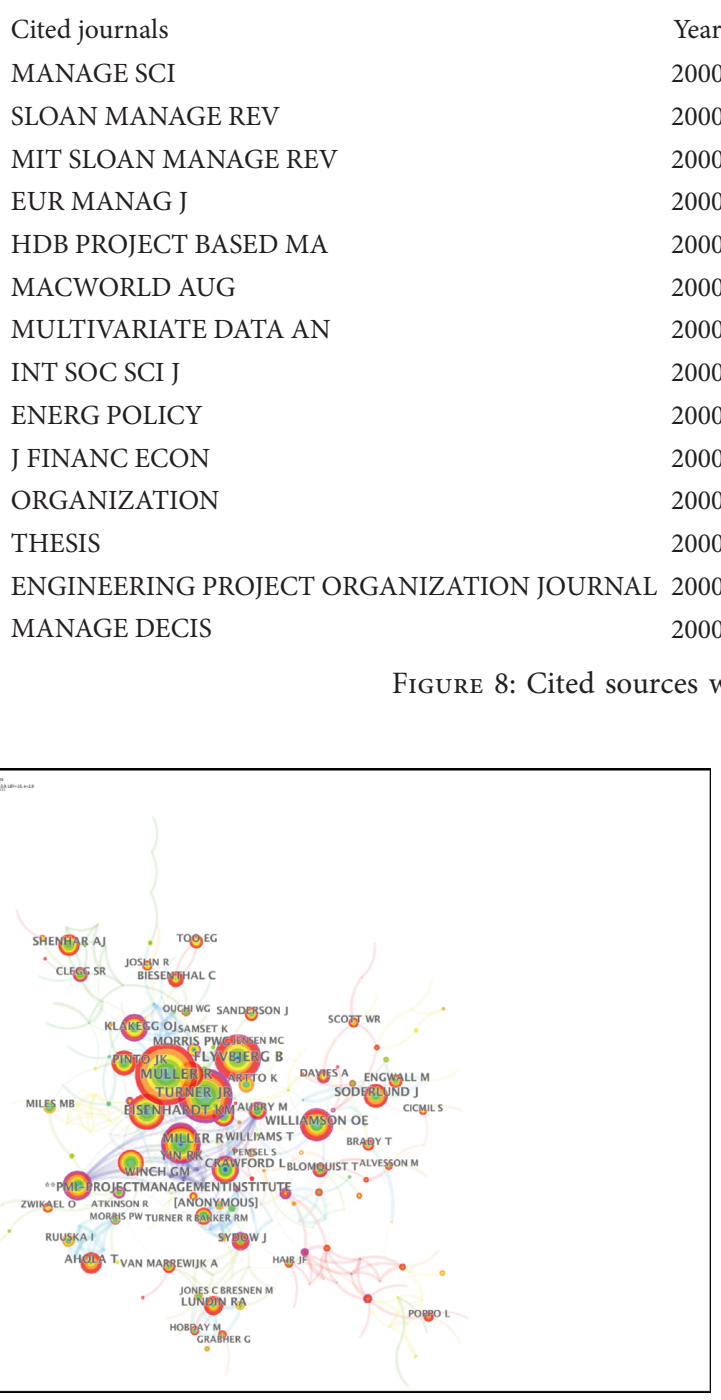

FIgURE 9: Network of author cocitation.

author, and the links between authors represent indirect cooperative relationships established based on cocitation frequency. Thus, the most highly cited authors were identified, including Müller R. (frequency=108), Turner J. R. $($ frequency $=81)$, Flyvbjerg B. (frequency $=77$ ), Eisenhardt K. M. (frequency=63), Miller R. (frequency=61), Williamson O. E. (frequency = 54), Yin R. (frequency = 53), PMI (frequency $=48$ ), Winch G.M. (frequency $=48$ ), Pinto J. K. (frequency $=48)$, Crawford L. (frequency $=47)$, Morris P. $($ frequency $=46)$, Soderlund J. (frequency $=43$ ), Klakegg O. J. (frequency $=40)$, Williams T. (frequency $=39$ ), Ahola T. (frequency $=39)$, Shenhar A. (frequency $=39)$, Lundin R. A. (frequency $=35)$, Aubry M. (frequency $=32$ ), and Biesenthal C. (frequency $=30$ ). Eisenhardt K. M. and Yin R. actively lead research on the case study method. Their appearance in the list might mean that most PG research studies were conducted on case study. Williamson O. E.'s theory is one of the fundamental theories of PG research. The top 20 most highly cited authors include one global nonprofit professional organization (Project Management Institute, PMI) in the US and 19 research scholars. The locations of these most highly cited authors demonstrate that PG research has been performed mostly in Scandinavia countries, the UK, and North America.

Among the authors with high betweenness centralities, nodes with an outer purple ring in the collaboration network, Turner J. R., Dyer J. H., Miller R., Klakegg O. J., and Atkinson R. are prominent authors with significant volume. A highly cited author does not necessarily receive a high betweenness centrality. However, when an author simultaneously receives a high citation count and a high betweenness centrality, this author is very likely to have a fundamental influence on the development and evolution of PG research. Such authors include Turner J. R., Miller R., and Klakegg O. J.

Furthermore, several authors have had citation bursts, with rapid increases in citation frequency over short periods. Such authors include Jensen M. C. (burst strength of 4.83, from 2013 to 2016), Williams T. M. (3.84, 2014-2016), Crawford L. (3.82, 2010-2011), Morris P. (3.81, 2012-2014), Killen C. P. (3.76, 2012-2014), and Merrow E. W. (3.59, 2016-2017). Specifically, articles published by Manning S., Eriksson P. E., and Poppo L. are worth following because they had strong citation in the past three years and may affect the direction of project governance research.

3.2.3. Analysis of Document Cocitation. By using CiteSpace, 13068 references cited in the 285 articles are analyzed and presented in Figure 10. The network was pruned by the pathfinder function in CiteSpace. The top 17 reference articles according to their citation frequency $(\geq 15)$ are listed in Table 3. Among these, the most highly cited reference summarized the process, roles, and accountabilities of managers chartered with project governance [38]. Based on transaction costs economics, agency theory, and institutional theory, he developed a theoretical model to address project governance at different levels. Moreover, Müller [39] studied nine cases to discuss how to build trust through project governance structures and explored three governance levels (governmentality, governance of projects, and 


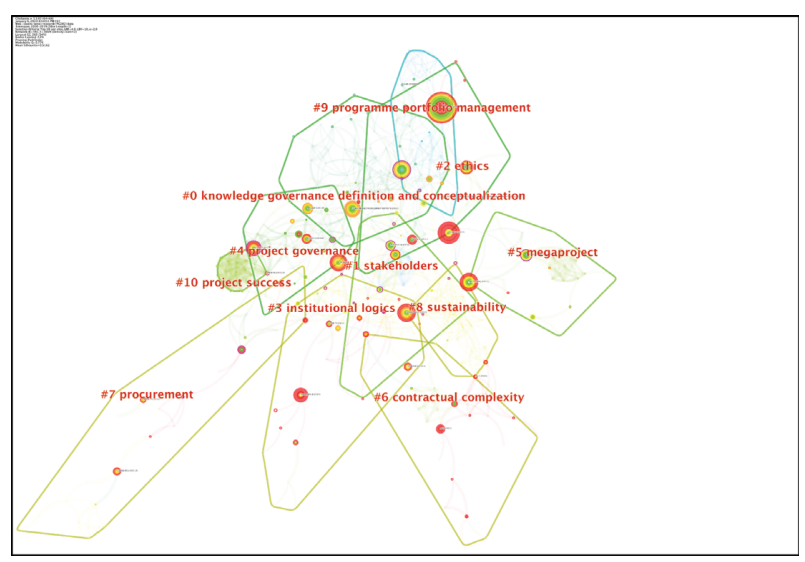

FIGURE 10: Network of references cocitation.

project governance) [2]. Literature review articles that identified concept [18, 19], origins [18], and levels [1] of project governance got researchers' attention and appeared in the list. In addition, several articles adopted the case studies method to investigate governance in projects. For example, Williams et al. [40] looked at four cases to investigate public investment project governance frameworks. Ruuska et al. [10] analyzed governance in two multifirm projects and proposed an integrated governance approach.

Nodes with high betweenness centralities, as indicated by purple rings, are also marked in Figure 10. According to [28], it is possible that these nodes lead to insights into emerging trends, as they connect aggregated cocitation clusters. Among them, remarkable betweenness centrality values appear for the documents of Zwikael and Smyrk [23] (centrality $=0.2)$, Smyth and Edkins [41] (centrality $=0.19)$, Davies et al. [42] (centrality $=0.16$ ), van Marrewijk et al. [43] (centrality =0.15), Davies and Mackenzie [44] (centrality $=0.15)$, and Klakegg et al. [13] (centrality=0.14). It indicated that these documents represented major intellectual turning points and milestones in PG research.

3.2.4. Analysis of Cocitation Clusters. Based on the document cocitation analysis, a total of 11 significant cocitation clusters were identified, as shown in Figure 10. Following Chen [28] suggestion, the LLR algorithm was employed to select the best cluster labels in terms of uniqueness and coverage. The labels of these nine clusters were the default naming patterns of the LLR cluster. The clusters are numbered in the descending order of the cluster size. The Modularity $Q$ value of 0.776 is relatively high, which means that the specialties in project governance are clearly defined. The mean silhouette score is 0.516 , suggesting that the homogeneity of these clusters on average is not very high. This might be because of the small samples and numerous small clusters.

Table 4 lists the 11 major clusters by their sizes, i.e., the number of members in each cluster. Thus, Cluster \#0 "knowledge governance," with 49 members, was the largest one, while Cluster \#10 "project success" was the smallest one, with 20 members. The table shows that all the silhouette scores are higher than 0.65 , which means that all the clusters are of high homogeneity or consistency. To avoid potential misunderstanding of the automatic labels, alternative labels including the terms with the top LLR scores are shown in the table as well. Mean year, i.e., the average year of publication of a cluster, indicates its recentness. For example, the most recently formed clusters, Cluster \#3 on institutional logics, Cluster \#6 on contractual complexity, and Cluster \#8 on sustainability have an average year of 2012. Cluster \#9 is formed by older documents than other clusters.

The largest Cluster \#0 "knowledge governance" has 49 members and across a 11-year period. Its silhouette value of 0.654 is the lowest of the 11 clusters, but this is generally considered a relatively high level of homogeneity. The representative documents were by PMI [3] with a citation frequency of 24 and Müller et al. [39] with a citation frequency of 18. PMI [3] offered practical guidance for effective project governance in projects. Müller et al. [39] viewed the governance structure as "the mechanism through which governance is executed" and investigated interaction between the governance structure and the individuals in projects. In terms of active citing articles, Winch [45], citing $38 \%$ of the cited references in this cluster, defined governance as one of three domains of project organization. Pemsel et al. [57], citing 30\% of the cited references in this cluster, addressed macro- and microlevel governance in project-based organizations.

Cluster \#1 "stakeholders" has 39 members and a silhouette value of 0.734 . This cluster can be summarized as focusing on "public projects" because it discusses the challenges and strategies for facilitating project governance and highlights policies and regulations related to public projects. The representative document was published by Ruuska et al. [10], in which a governance approach based on network view was proposed in nuclear projects. Klakegg et al. [13] compared the governance system of public projects in Norway and UK to find out how to ensure that projects meet their purposes. The most active citing document in this cluster is that of Lappi and Aaltonen [14], having the citation coverage of $25.6 \%$ and analyzing the project governance practices in three case projects of the Finnish public sector. Among the remaining active citing articles, project governance in public projects has been widely discussed. Joslin and Müller [58] showed that public investment projects were subject to stricter governance approaches than projects in a smaller scale. Objectives of public projects should be aligned with policies, and the top-down policy implementation affects the effectiveness of the project governance system $[59,60]$. As public projects are policy implementation tools for accomplishing government's programs, linking policies is the key governance practice in this kind of projects that needs to be followed [61].

Cluster \#2 labeled as "ethics" has a silhouette value of 0.820 . The representative document was the book by Müller [38], which described the role of the steering group as the main agency for project governance. The governance structure of the project should be aligned with organizational settings [18]. The most active citing document in this cluster is that of [46] (citation coverage $=29.4 \%$ ), which 
TABLE 3: Top 17 cited references.

\begin{tabular}{|c|c|c|c|c|c|c|c|c|}
\hline No. & $\begin{array}{c}\text { Citation } \\
\text { counts }\end{array}$ & $\begin{array}{c}\text { Betweenness } \\
\text { centrality }\end{array}$ & Author(s) & Title & Source & $\begin{array}{c}\text { Publication } \\
\text { year }\end{array}$ & $\begin{array}{l}\text { Type of } \\
\text { source }\end{array}$ & $\begin{array}{c}\text { Cluster } \\
\#\end{array}$ \\
\hline 1 & 47 & 0.09 & Müller R. & Project governance & MPG Books & 2009 & Book & 2 \\
\hline 2 & 33 & 0.04 & Ahola T. et al. & $\begin{array}{l}\text { What is project governance and } \\
\text { what are its origins? }\end{array}$ & $\begin{array}{l}\text { International } \\
\text { Journal of Project } \\
\text { Management }\end{array}$ & 2014 & $\begin{array}{l}\text { Journal } \\
\text { article }\end{array}$ & 2 \\
\hline 3 & 29 & 0.16 & Sanderson J. & $\begin{array}{c}\text { Risk, uncertainty, and } \\
\text { governance in megaprojects: a } \\
\text { critical discussion of alternative } \\
\text { explanations }\end{array}$ & $\begin{array}{l}\text { International } \\
\text { Journal of Project } \\
\text { Management }\end{array}$ & 2012 & $\begin{array}{l}\text { Journal } \\
\text { article }\end{array}$ & 5 \\
\hline 4 & 28 & 0.03 & $\begin{array}{l}\text { Too E. and } \\
\text { Weaver P. }\end{array}$ & $\begin{array}{l}\text { The management of project } \\
\text { management: a conceptual } \\
\text { framework for project } \\
\text { governance }\end{array}$ & $\begin{array}{l}\text { International } \\
\text { Journal of Project } \\
\text { Management }\end{array}$ & 2014 & $\begin{array}{l}\text { Journal } \\
\text { article }\end{array}$ & 4 \\
\hline 5 & 27 & 0 & $\begin{array}{l}\text { Biesentha, C. } \\
\text { and Wilden } \\
\text { R. }\end{array}$ & $\begin{array}{l}\text { Multilevel project governance: } \\
\text { trends and opportunities }\end{array}$ & $\begin{array}{l}\text { International } \\
\text { Journal of Project } \\
\text { Management } \\
\text { Project }\end{array}$ & 2014 & $\begin{array}{l}\text { Journal } \\
\text { article }\end{array}$ & 8 \\
\hline 6 & 26 & 0.07 & PMI & $\begin{array}{l}\text { A guide to the project } \\
\text { management body of knowledge }\end{array}$ & $\begin{array}{l}\text { Project } \\
\text { Management } \\
\text { Institute }\end{array}$ & 2013 & Book & 0 \\
\hline 7 & 25 & 0.11 & Yin R. K. & $\begin{array}{l}\text { Case study research: design and } \\
\text { methods }\end{array}$ & $\begin{array}{c}\text { SAGE } \\
\text { Publications }\end{array}$ & 2009 & Book & 2 \\
\hline 8 & 23 & 0.07 & Flyvbjerg B. & $\begin{array}{c}\text { What you should know about } \\
\text { megaprojects and why: an } \\
\text { overview }\end{array}$ & $\begin{array}{c}\text { Project } \\
\text { Management } \\
\text { Journal }\end{array}$ & 2014 & $\begin{array}{l}\text { Journal } \\
\text { article }\end{array}$ & 3 \\
\hline 9 & 22 & 0.02 & $\begin{array}{l}\text { Williams T. } \\
\text { et al. }\end{array}$ & $\begin{array}{l}\text { An investigation of governance } \\
\text { frameworks for public projects in } \\
\text { Norway and the UK. }\end{array}$ & $\begin{array}{l}\text { International } \\
\text { Journal of Project } \\
\text { Management }\end{array}$ & 2010 & $\begin{array}{l}\text { Journal } \\
\text { article }\end{array}$ & 2 \\
\hline 10 & 21 & 0.13 & $\begin{array}{l}\text { Müller R. } \\
\text { et al. }\end{array}$ & $\begin{array}{l}\text { Organizational enablers for } \\
\text { governance and governmentality } \\
\text { of projects: a literature review }\end{array}$ & $\begin{array}{l}\text { International } \\
\text { Journal of Project } \\
\text { Management }\end{array}$ & 2014 & $\begin{array}{l}\text { Journal } \\
\text { article }\end{array}$ & 10 \\
\hline 11 & 18 & 0.08 & $\begin{array}{l}\text { Müller R. } \\
\text { et al. }\end{array}$ & $\begin{array}{l}\text { The interrelationship of } \\
\text { governance, trust, and ethics in } \\
\text { temporary organizations }\end{array}$ & $\begin{array}{l}\text { Project } \\
\text { Management } \\
\text { Journal }\end{array}$ & 2013 & $\begin{array}{l}\text { Journal } \\
\text { article }\end{array}$ & 0 \\
\hline 12 & 18 & 0.06 & $\begin{array}{l}\text { Miller R. and } \\
\text { Hobbs B. }\end{array}$ & $\begin{array}{l}\text { Governance regimes for large } \\
\text { complex projects }\end{array}$ & $\begin{array}{c}\text { Project } \\
\text { Management } \\
\text { Journal }\end{array}$ & 2005 & $\begin{array}{l}\text { Journal } \\
\text { article }\end{array}$ & 13 \\
\hline 13 & 17 & 0.03 & $\begin{array}{l}\text { Ruuska I. } \\
\text { et al. }\end{array}$ & $\begin{array}{l}\text { A new governance approach for } \\
\text { multifirm projects: lessons from } \\
\text { Olkiluoto } 3 \text { and Flamanville } 3 \\
\text { nuclear power plant projects }\end{array}$ & $\begin{array}{l}\text { International } \\
\text { Journal of Project } \\
\text { Management }\end{array}$ & 2011 & $\begin{array}{l}\text { Journal } \\
\text { article }\end{array}$ & 1 \\
\hline 14 & 16 & 0.05 & $\begin{array}{l}\text { Müller R. and } \\
\text { Lecoeuvre L }\end{array}$ & $\begin{array}{l}\text { Operationalizing governance } \\
\text { categories of projects }\end{array}$ & $\begin{array}{l}\text { International } \\
\text { Journal of Project } \\
\text { Management }\end{array}$ & 2014 & $\begin{array}{l}\text { Journal } \\
\text { article }\end{array}$ & 4 \\
\hline 15 & 16 & 0.01 & $\begin{array}{l}\text { Lundin R. A. } \\
\text { et al. }\end{array}$ & $\begin{array}{l}\text { Managing and working in } \\
\text { project society: institutional } \\
\text { challenges of temporary } \\
\text { organizations. }\end{array}$ & $\begin{array}{l}\text { Cambridge } \\
\text { University Press }\end{array}$ & 2015 & Book & 5 \\
\hline 16 & 16 & 0.15 & $\begin{array}{l}\text { van } \\
\text { Marrewijk A. } \\
\text { et al. }\end{array}$ & $\begin{array}{l}\text { Managing public-private } \\
\text { megaprojects: paradoxes, } \\
\text { complexity, and project design }\end{array}$ & $\begin{array}{l}\text { International } \\
\text { Journal of Project } \\
\text { Management }\end{array}$ & 2008 & $\begin{array}{l}\text { Journal } \\
\text { article }\end{array}$ & 11 \\
\hline 17 & 15 & 0.08 & Pinto J. K. & $\begin{array}{c}\text { Project management, } \\
\text { governance, and the } \\
\text { normalization of deviance }\end{array}$ & $\begin{array}{l}\text { International } \\
\text { Journal of Project } \\
\text { Management }\end{array}$ & 2014 & Book & 2 \\
\hline
\end{tabular}

helped managers select or adjust the governance structures to achieve the project objectives. Besides, Aubry et al. [62] revealed the existence of the hierarchy governance structure consisting of the executives and the project management offices. Further analysis suggested that stakeholder theory should be applied as a primary lens to study project governance [21]. The short-term view governance mechanisms may be updated to long-term perspective, not only focusing on project itself, but also on the project stakeholders and organization. Thus, this cluster can be summarized as "governance structure," which refers to issues about involvement of stakeholders and organizations. In the 
TABLE 4: Research clusters in the field of project governance.

\begin{tabular}{|c|c|c|c|c|c|c|c|}
\hline $\begin{array}{l}\text { Cluster } \\
\text { no. }\end{array}$ & Size & Silhouette & $\begin{array}{c}\text { Cluster label } \\
\text { (LLR) }\end{array}$ & Alternative labels & $\begin{array}{c}\text { Representative } \\
\text { documents }\end{array}$ & $\begin{array}{l}\text { Most representative } \\
\text { citing documents }\end{array}$ & $\begin{array}{c}\text { Mean } \\
\text { year }\end{array}$ \\
\hline 0 & 49 & 0.654 & $\begin{array}{l}\text { Knowledge } \\
\text { governance }\end{array}$ & $\begin{array}{l}\text { Complex project management; } \\
\text { common will; top management team } \\
(\mathrm{tmt})\end{array}$ & $\begin{array}{l}\text { PMI [3], } \\
\text { Müller et al. [39] }\end{array}$ & Winch [45] & 2008 \\
\hline 1 & 39 & 0.734 & Stakeholders & $\begin{array}{c}\text { Public sector; public investment } \\
\text { projects; agile; policy; construction } \\
\text { headquarter }\end{array}$ & $\begin{array}{l}\text { Turner [4], } \\
\text { Ruuska et al. [10], } \\
\text { Ahola et al. [18] }\end{array}$ & $\begin{array}{c}\text { Lappi and } \\
\text { Aaltonen [14] }\end{array}$ & 2011 \\
\hline 2 & 34 & 0.820 & Ethics & $\begin{array}{l}\text { Governance of projects; governance } \\
\text { of project management; decision- } \\
\text { making; path creation }\end{array}$ & Müller [38] & $\begin{array}{l}\text { Müller and } \\
\text { Lecoeuvre [46], } \\
\text { Joslin and } \\
\text { Müller [47] }\end{array}$ & 2010 \\
\hline 3 & 32 & 0.744 & $\begin{array}{c}\text { Institutional } \\
\text { logics }\end{array}$ & $\begin{array}{l}\text { Construction project management; } \\
\text { ppps; business model design; benefit } \\
\text { management }\end{array}$ & $\begin{array}{c}\text { Biesenthal and } \\
\text { Wilden [1], Flyvbjerg } \\
\text { [37] }\end{array}$ & $\begin{array}{l}\text { Too and } \\
\text { Weaver [19], } \\
\text { Badewi [48] }\end{array}$ & 2012 \\
\hline 4 & 32 & 0.752 & $\begin{array}{c}\text { Project } \\
\text { governance }\end{array}$ & $\begin{array}{l}\text { Comparative case study; strategy } \\
\text { execution; leximancer; risk } \\
\text { management; infrastructure } \\
\text { construction projects }\end{array}$ & Too and Weaver [19] & $\begin{array}{c}\text { Joslin and Müller } \\
{[47]}\end{array}$ & 2008 \\
\hline 5 & 24 & 0.932 & Megaproject & $\begin{array}{c}\text { Projects; project based; power plant } \\
\text { economics; collaboration; } \\
\text { ethnography; budget }\end{array}$ & Sanderson [49] & $\begin{array}{c}\text { van Marrewijk and } \\
\text { Smits [50] }\end{array}$ & 2009 \\
\hline 6 & 24 & 0.870 & $\begin{array}{l}\text { Contractual } \\
\text { complexity }\end{array}$ & $\begin{array}{l}\text { Contractual governance; governance } \\
\text { mechanisms; contractor behavior; } \\
\text { opportunistic behavior }\end{array}$ & Lu et al. [51] & Wang et al. [52] & 2012 \\
\hline 7 & 24 & 0.936 & Procurement & $\begin{array}{c}\text { Infrastructure; alliance; construction } \\
\text { megaprojects; ipd; institutional } \\
\text { entrepreneur }\end{array}$ & Lahdenperä [53] & Kivilä et al. [54] & 2010 \\
\hline 8 & 23 & 0.851 & Sustainability & $\begin{array}{c}\text { Public engagement; specific } \\
\text { investments; infrastructure } \\
\text { development; formal control; risk } \\
\text { governance }\end{array}$ & $\begin{array}{l}\text { Biesenthal and } \\
\text { Wilden [1] }\end{array}$ & Kivilä et al. [54] & 2012 \\
\hline 9 & 22 & 0.909 & $\begin{array}{l}\text { Programme } \\
\text { portfolio } \\
\text { management }\end{array}$ & $\begin{array}{l}\text { Hong Kong special administrative } \\
\text { region; information acquisition; } \\
\text { uncertainty; quantitative study }\end{array}$ & Müller et al. [39] & Mosavi [55] & 2006 \\
\hline 10 & 20 & 0.979 & Project success & $\begin{array}{l}\text { Benefits management; project } \\
\text { management theory; project } \\
\text { management success; project } \\
\text { management methodology }\end{array}$ & Müller et al. [2] & $\begin{array}{l}\text { Badewi and } \\
\text { Shehab [56] }\end{array}$ & 2011 \\
\hline
\end{tabular}

project governance scheme, project management offices, entitled with project governance tasks, have a central role [63]. In addition, other units, including functional departments and the top management, share the similar governance tasks with project management offices [63].

Cluster \#3 “institutional logics" can be summarized to "governance context." It consists of 32 members, and its silhouette value is 0.744 . The representative document in this cluster was published by Flyvbjerg [37] pointing out what should be considered in governing megaprojects. As "no project is an island" [64], project governance practices should be extended to a broader scope, especially when the context is complex [24]. The most active citing document was published by Badewi [48] (citation coverage $=24 \%$ ), in which a project governance framework combining benefit management and project management practices was proposed to enhance the probability of project success. Support for this is indicated by Joslin and Müller [47], who showed that project governance was a quasi-moderator in the relationship between project management methodology and project success. Empirical studies have confirmed that managers should consider anchoring the project to the institutional environment when designing the structure of relational governance $[37,65]$. The institutional context, in which project stakeholders operate, is a function of the networks with which they are connected ([66], p. 216). Projects in an institutional environment operate under strict regulatory requirements, such as laws and policies. They also comply with normative systems, such as market rules and specialization.

Cluster \#4, labeled "project governance," has 32 members and a silhouette value of 0.752 . The most highly cited article, by Too and Weaver [19], viewed the governance framework as a hierarchical system, where the top level was accountable for the whole construction process. Turner [4] defined project governance as the practices aiming at achieving project objectives. Among the active citing articles, the project governance model or framework has been widely discussed. Bekker [5] formulated three project governance schools from the perspective of corporate governance, and 
Müller and Martinsuo [67] further extended corporate governance into the realm of projects. As Cluster \#0 and \#4 mainly focus on the governance framework and concept, the two clusters can be summarized as "conceptual framework." From the hierarchical perspective, the project governance framework was defined as organized structures and a set of principles to make projects possible and effective [13]. It refers to issues about involvement of stakeholders, especially the project manager's sovereignty and authority [35]. From the holistic perspective, Müller et al. [68] developed a framework structured by the governance and governmentality, within the context of projectification. Governmentality reflects how governors prioritize the project, and governance dimensions include sovereignty, mechanisms, and institutions. Projectification is "the extent to which an organization uses projects and their management as an underlying principle to conduct their work" [35].

Cluster \#5, labeled "megaprojects," primarily addresses project governance in megaprojects, or major projects. The top intellectual-basis document is by Sanderson [49], which examines different governance practices for megaproject performance. Governance structures and strategies influences project managers' capabilities in managing megaprojects [43]. The active citing document discussed how challenges of megaprojects were resolved through the right governance structure [69]. Governance of megaprojects is extremely complex due to the complex context, such as changing teams and organizational cultures [50]. In large public projects, or megaprojects, the owner is the government, who is ultimately on behalf of all citizens $[11,17]$. As noted by Too and Weaver [19], a governance framework is a hierarchical system, where the top level is accountable for the whole construction process.

Cluster \#6 labeled "contractual complexity" has 24 members and a silhouette value of 0.870 . The most highly cited article, by Lu et al. [51], contributed to the research on effectiveness of contractual and relational governances in construction projects. In low-risk situations, contractual governance at a higher level is more effective in improving performance [23]. The most active citing article offered a model to test the effect of transaction cost and relational governance [52]. In project, control and trust are "the endpoints of a continuum" [68] as complements of each other rather than substitutes [70]. As stand-alone mechanisms, contractual governance and relational governance are distinct yet inseparable parts of a governance system, and their relationship can be strongly moderated by project complexity [71].

Cluster \#7 labeled "procurement" has 24 members and a silhouette value of 0.936 , with alternative labels including infrastructure, alliance, and construction megaprojects. In fact, this cluster primarily addresses project governance as an integrated framework in infrastructure projects. Representative documents developed a framework of regulative, normative, and cognitive governance mechanisms [72] and how to establish a governance structure in a megaproject [42]. The most active citing documents endorsed the value of effective governance for maximizing infrastructure project performance [73]. Thus, this cluster and Cluster $\# 5$ can be summarized into "megaproject governance."
Cluster \#8, labeled as "sustainability" with 23 members has a silhouette value of 0.851 . The top intellectual-basis document is by Biesenthal and Wilden [1], in which project governance was explained at various project levels: level of project, level linking parent organization to project, and level of parent organization. Project governance at the highest level aims to improve continuously the sustainability of the projects. In the most active citers, research reviewed studies combining governance and sustainability [74] and pointed out how to implement project sustainability with the sustainable project governance approach [54].

Cluster \#9, labeled as "programme portfolio governance" has 22 members and a silhouette value of 0.909 . This cluster mainly focuses on governance in groups of projects, which is different from governance of a single project [1]. Müller [38] described program and portfolio governance as a governance structure for project-based organizations. The most active citing document in this cluster is that of [55] (citation coverage $=36 \%$ ), which explored relationship between program governance and steering committees. In portfolio governance, the steering committee performs as a communicator, negotiator, and decision maker. Young et al. [75] investigated differences between project and program governance in the context of state investment projects.

Cluster \#10, labeled "project success," primarily focuses on governance practices and their outcomes. Too and Weaver [19] provided key elements to support effective governance of projects. Müller and Jugdev [76] examined critical success factors in projects and advanced from narrower project management perspectives towards project governance. Active citing documents in this cluster supported the hypothesis that project governance can increase project success [48, 56]. Similarly, Guo et al. [77] examined the relationship between project governance and risk management. Arranz and de Arroyabe [78] examined the effect of governance mechanisms on project performance.

Through literature review, all of the 11 clusters can be summarized into 9 topics: (1) conceptual framework (Cluster \#0 and \#4), (2) public projects (Cluster \#1), (3) governance structure (Cluster \#2), (4) governance context (Cluster \#3), (5) megaproject governance (Cluster \#5 and \#7), (6) contractual and relational governance (Cluster \#6), (7) sustainability (Cluster \#8), (8) portfolio governance (Cluster \#9), and (9) project success (Cluster \#10). These results are consistent with those of previous studies [21, 22, 49].

Major references in the development of PG can be identified from the list of references that have strong citation bursts, as shown in Figure 11. Miller and Hobbs [65] (with a burst strength of 6.84, from 2011 to 2015), Flyvbjerg [37] ( strength $=4.86,2018-2019$ ), and Turner [4] (strength $=4.74$, 2017-2018) received the highest burst strength, which means the citations of them increased significantly over a short period. Besides, articles which got citation bursts in the past two years were worthy of being followed, such as Lundin [79], Ahola et al. [18], Ruuska et al. [10], Brady and Davies [80], and $\mathrm{Lu}$ et al. [51]. As most of the citation bursts appeared in Cluster \#1, \#2, and \#4, it can be viewed that the conceptual framework, public projects, and governance structure would draw more attention in research. 


References
MILLER R, 2005, PROJ MANAG J, V36, P42, DOI
MULLER R, 2009, PROJECT GOVERNANCE, V0, P0
PEMSEL S, 2012, INT J PROJ MANAG, V30, P865, DOI
TURNER JR, 2009, HDB PROJECT BASED MA, V0, P0
JUDGEV K, 2005, PROJ MANAG J, V36, P19, DOI
SAMSET K, 2016, INT J PROJ MANAG, V34, P297, $\underline{\text { DOI }}$
LUNDIN RA, 2015, MANAGING WORKING PRO, V0, P0 2015
AHOLA T, 2014, INT J PROJ MANAG, V32, P1321, $\underline{\text { DOI }}$
RUUSKA I, 2011, INT J PROJ MANAG, V29, P647, $\underline{\text { DOI }}$
JONES C, 2008, OXFORD HDB INTERORGA, V0, P231
BRADY T, 2014, PROJ MANAG J, V45, P21, DOI
LU P, 2015, INT J PROJ MANAG, V33, P212, $\underline{\text { DOI }}$
FLYVBJERG B, 2014, PROJ MANAG J, V45, P6, $\underline{\text { DOI }}$

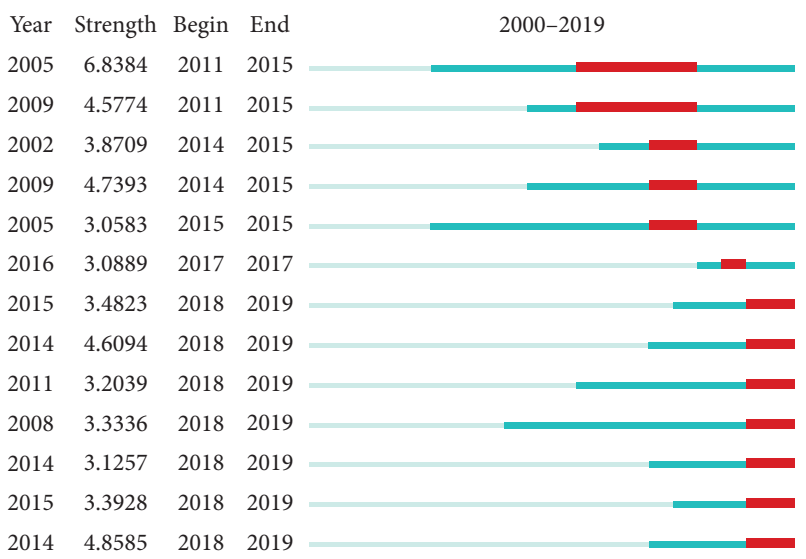

FIgURE 11: Top references with strong citation bursts.

\section{Conclusions}

This study conducted a scientometric review to explore the development track and trends of global project governance research. A total of 285 bibliographic records were collected from the Web of Science Core Collection database and analyzed via coauthor analysis, coword analysis, and cocitation analysis to identify and visualize the project governance research.

Based on coauthorship and author cocitation analysis, Müller R., Klakegg O. J., and Aubry M. were identified as the top three most productive authors in the field and Müller R. and Turner J. R. were the most cited authors. Additionally, comparisons between the most productive with the most influential authors indicated that not all highly productive authors have significant influence on PG research, where some researchers (e.g., Miller R. and Winch G. M.) without many publications can still have high cocitation frequencies. It was also found that BI Norwegian Business School, Norwegian University of Science Technology, and University of Technology Sydney were the most productive institutions. The most cited authors all come from or have relationships with Scandinavia countries, UK, and North America.

Regarding high-frequency keywords, project success and megaproject received high betweenness centrality as well as citation burst in the most recent years. It represents that the research on them may be new developments and possibly the major frontiers in the project governance domain.

The results of document cocitation analysis indicated the knowledge domains of project governance research. 11 cocitation clusters were identified based on the terms associated with the analyzed documents, and the focuses of these clusters can be summarized into 9 topics: conceptual framework, public projects, governance structure, governance context, megaproject governance, contractual and relational governance, sustainability, portfolio governance, and project success. Among those topics, the conceptual framework of project governance has been discussed for 13 years, which may represent that it has not come to an agreement on how the project governance framework should be understood. Moreover, the focus governance conceptual framework, public projects, and governance structure were detected as important domains.

This study provides valuable information for the researcher in the field of project governance. The analysis on key scholars and research institutions, important sources for publication, and hot topics provides insights for researchers. From methodological perspective, this study applies CiteSpace to conduct a bibliometric citation analysis. Compared to extant integrated research studies and reviews in governance, both network maps and information tables were presented to show the status of project governance more comprehensively. This method can be applied in other areas, using different search keywords. Moreover, the important practical implication is that practitioners can select appropriate governance procedures based on the results.

Some limitations associated with this study should be noted. First, the scope of the data is limited by the source of the retrieval and the query terms. Other sources such as Scopus would provide additional insights. Second, when it comes to CiteSpace, the analysis results might be different due to the different parameter settings used by the researcher. Further studies could try to solve these problems by applying both qualitative and systematic literature review techniques to extend the findings herein.

\section{Conflicts of Interest}

The authors declare that they have no conflicts of interest.

\section{Acknowledgments}

This study was supported by the National Natural Science Foundation of China (project number: 71901224), Central South University (project number: 202045013), and Open Fund of Engineering Research Center of Catastrophic Prophylaxis and Treatment of Road and Traffic Safety of the Ministry of Education (Changsha University of Science and Technology, no. kfj190404). 


\section{References}

[1] C. Biesenthal and R. Wilden, "Multi-level project governance: trends and opportunities," International Journal of Project Management, vol. 32, no. 8, pp. 1291-1308, 2014.

[2] R. Müller, S. Pemsel, and J. Shao, "Organizational enablers for governance and governmentality of projects: a literature review," International Journal of Project Management, vol. 32, no. 8, pp. 1309-1320, 2014.

[3] PMI, A Guide to the Project Management Body of Knowledge (PMBOK ${ }^{\circledR}$ Guide), Project Management Institute, Newtown Square, PA, USA, 2013.

[4] J. R. Turner, Handbook of Project-Based Management, pp. 309-322, McGraw-Hill, London, UK, 2009.

[5] M. C. Bekker, "Project governance: "schools of thought"," South African Journal of Economic and Management Sciences, vol. 17, no. 1, pp. 22-32, 2014.

[6] G. H. Volden and K. Samset, "Governance of major public investment projects: principles and practices in six countries," Project Management Journal, vol. 48, no. 3, pp. 90-108, 2017.

[7] I. C. Cardenas, H. Voordijk, and G. Dewulf, "Beyond theory: towards a probabilistic causation model to support project governance in infrastructure projects," International Journal of Project Management, vol. 35, no. 3, pp. 432-450, 2017.

[8] M. Brunet, "Governance-as-practice for major public infrastructure projects: a case of multilevel project governing," International Journal of Project Management, vol. 37, no. 2, pp. 283-297, 2019.

[9] O. Klakegg and T. Haavaldsen, "Governance of major public investment projects: in pursuit of relevance and sustainability," International Journal of Managing Projects in Business, vol. 4, no. 1, pp. 157-167, 2011.

[10] I. Ruuska, T. Ahola, K. Artto, G. Locatelli, and M. Mancini, “A new governance approach for multi-firm projects: lessons from Olkiluoto 3 and Flamanville 3 nuclear power plant projects," International Journal of Project Management, vol. 29, no. 6, pp. 647-660, 2011.

[11] G. H. Volden and B. Andersen, "The hierarchy of public project governance frameworks," International Journal of Managing Projects in Business, vol. 11, no. 1, pp. 174-197, 2018.

[12] M. Brunet and M. Aubry, "The governance of major public infrastructure projects: the process of translation," International Journal of Managing Projects in Business, vol. 11, no. 1, pp. 80-103, 2018.

[13] O. J. Klakegg, T. Williams, O. M. Magnussen, and H. Glasspool, "Governance frameworks for public project development and estimation," Project Management Journal, vol. 39, no. 1, pp. S27-S42, 2008.

[14] T. Lappi and K. Aaltonen, "Project governance in public sector agile software projects," International Journal of Managing Projects in Business, vol. 10, no. 2, pp. 263-294, 2017.

[15] N. J. Brookes and G. Locatelli, "Power plants as megaprojects: using empirics to shape policy, planning, and construction management," Utilities Policy, vol. 36, pp. 57-66, 2015.

[16] H. E. A. Baharuddin, C. Ibrahim, S. B. Costello, and S. Wilkinson, "Managing stakeholders through alliances: a case study of a megaproject in New Zealand," Proceedings of the Institution of Civil Engineers-Management Procurement and Law, vol. 170, no. 4, pp. 151-160, 2017.

[17] Z. Zhai, T. Ahola, Y. Le, and J. Xie, "Governmental governance of megaprojects: the case of EXPO 2010 Shanghai," Project Management Journal, vol. 48, no. 1, pp. 37-50, 2017.
[18] T. Ahola, I. Ruuska, K. Artto, and J. Kujala, "What is project governance and what are its origins?," International Journal of Project Management, vol. 32, no. 8, pp. 1321-1332, 2014.

[19] E. G. Too and P. Weaver, "The management of project management: a conceptual framework for project governance," International Journal of Project Management, vol. 32, no. 8, pp. 1382-1394, 2014.

[20] T. Lappi, T. Karvonen, L. E. Lwakatare, K. Aaltonen, and P. Kuvaja, "Toward an improved understanding of agile project governance," Project Management Journal, vol. 49, no. 6, pp. 39-63, 2018.

[21] R. Derakhshan, R. Turner, and M. Mancini, "Project governance and stakeholders: a literature review," International Journal of Project Management, vol. 37, no. 1, pp. 98-116, 2019.

[22] A. ul Musawir, S. B. Abd-Karim, and M. S. Mohd-Danuri, "Project governance and its role in enabling organizational strategy implementation: a systematic literature review," International Journal of Project Management, vol. 38, no. 1, pp. 1-16, 2020.

[23] O. Zwikael and J. Smyrk, "Project governance: balancing control and trust in dealing with risk," International Journal of Project Management, vol. 33, no. 4, pp. 852-862, 2015.

[24] T. S. Pitsis, S. Sankaran, S. Gudergan, and S. R. Clegg, "Governing projects under complexity: theory and practice in project management," International Journal of Project Management, vol. 32, no. 8, pp. 1285-1290, 2014.

[25] PMI, Governance of Portfolios, Programs, and Projects, Project Management Institute, Newtown Square, PA, USA, 2016.

[26] L. Bornmann and L. Leydesdorff, "Scientometrics in a changing research landscape," EMBO Reports, vol. 15, no. 12, pp. 1228-1232, 2014.

[27] J. Mingers and L. Leydesdorff, "A review of theory and practice in scientometrics," European Journal of Operational Research, vol. 246, no. 1, pp. 1-19, 2015.

[28] C. Chen, “The CiteSpace manual," 2014, http://cluster.ischool. drexel.edu/ cchen/citespace/CiteSpaceManual.pdf.

[29] C. Chen, Z. Hu, S. Liu, and H. Tseng, "Emerging trends in regenerative medicine: a scientometric analysis in CiteSpace," Expert Opinion on Biological Therapy, vol. 12, no. 5, pp. 593-608, 2012.

[30] L. B. de Rezende, P. Blackwell, and M. D. Pessanha Gonçalves, "Research focuses, trends, and major findings on project complexity: a bibliometric network analysis of 50 years of project complexity research," Project Management Journal, vol. 49, no. 1, pp. 42-56, 2018.

[31] X. Zhao, "A scientometric review of global BIM research: analysis and visualization," Automation in Construction, vol. 80 , pp. 37-47, 2017.

[32] T. Ganbat, H.-Y. Chong, P.-C. Liao, and Y.-D. Wu, "A bibliometric review on risk management and building information modeling for international construction," Advances in Civil Engineering, vol. 2018, Article ID 8351679, 13 pages, 2018.

[33] J. Song, H. Zhang, and W. Dong, "A review of emerging trends in global PPP research: analysis and visualization," Scientometrics, vol. 107, no. 3, pp. 1111-1147, 2016.

[34] A. U. Musawir, C. E. M. Serra, O. Zwikael, and I. Ali, "Project governance, benefit management, and project success: towards a framework for supporting organizational strategy implementation," International Journal of Project Management, vol. 35, no. 8, pp. 1658-1672, 2017.

[35] R. Müller, L. Zhai, and A. Wang, "Governance and governmentality in projects: profiles and relationships with 
success," International Journal of Project Management, vol. 35, no. 3, pp. 378-392, 2017.

[36] A. van Marrewijk, S. Ybema, K. Smits, S. Clegg, and T. Pitsis, "Clash of the titans: temporal organizing and collaborative dynamics in the Panama canal megaproject," Organization Studies, vol. 37, no. 12, pp. 1745-1769, 2016.

[37] B. Flyvbjerg, "What you should know about megaprojects and why: an overview," Project Management Journal, vol. 45, no. 2 , pp. 6-19, 2014.

[38] R. Müller, Project Governance, Gower Publishing Limited, Aldershot, UK, 2009.

[39] R. Müller, E. S. Andersen, Ø. Kvalnes et al., "The interrelationship of governance, trust, and ethics in temporary organizations," Project Management Journal, vol. 44, no. 4, pp. 26-44, 2013.

[40] T. Williams, O. J. Klakegg, O. M. Magnussen, and H. Glasspool, "An investigation of governance frameworks for public projects in Norway and the UK," International Journal of Project Management, vol. 28, no. 1, pp. 40-50, 2010.

[41] H. Smyth and A. Edkins, "Relationship management in the management of PFI/PPP projects in the UK," International Journal of Project Management, vol. 25, no. 3, pp. 232-240, 2007.

[42] A. Davies, D. Gann, and T. Douglas, "Innovation in megaprojects: systems integration at London Heathrow Terminal 5," California Management Review, vol. 51, no. 2, pp. 101-125, 2009.

[43] A. van Marrewijk, S. R. Clegg, T. S. Pitsis, and M. Veenswijk, "Managing public-private megaprojects: paradoxes, complexity, and project design," International Journal of Project Management, vol. 26, no. 6, pp. 591-600, 2008.

[44] A. Davies and I. Mackenzie, "Project complexity and systems integration: constructing the London 2012 olympics and paralympics games," International Journal of Project Management, vol. 32, no. 5, pp. 773-790, 2014.

[45] G. M. Winch, "Three domains of project organising," International Journal of Project Management, vol. 32, no. 5, pp. 721-731, 2014.

[46] R. Müller and L. Lecoeuvre, "Operationalizing governance categories of projects," International Journal of Project Management, vol. 32, no. 8, pp. 1346-1357, 2014.

[47] R. Joslin and R. Müller, "Relationships between a project management methodology and project success in different project governance contexts," International Journal of Project Management, vol. 33, no. 6, pp. 1377-1392, 2015.

[48] A. Badewi, "The impact of project management (PM) and benefits management (BM) practices on project success: towards developing a project benefits governance framework," International Journal of Project Management, vol. 34, no. 4, pp. 761-778, 2016.

[49] J. Sanderson, "Risk, uncertainty and governance in megaprojects: a critical discussion of alternative explanations," International Journal of Project Management, vol. 30, no. 4, pp. 432-443, 2012.

[50] A. van Marrewijk and K. Smits, "Cultural practices of governance in the Panama canal expansion megaproject," International Journal of Project Management, vol. 34, no. 3, pp. 533-544, 2016.

[51] P. Lu, S. Guo, L. Qian, P. He, and X. Xu, "The effectiveness of contractual and relational governances in construction projects in China," International Journal of Project Management, vol. 33, no. 1, pp. 212-222, 2015.

[52] D. Wang, S. Fang, and H. Fu, "The effectiveness of evolutionary governance in mega construction projects: a moderated mediation model of relational contract and transaction cost," Journal of Civil Engineering and Management, vol. 25, no. 4, pp. 340-352, 2019.

[53] P. Lahdenperä, "Making sense of the multi-party contractual arrangements of project partnering, project alliancing and integrated project delivery," Construction Management and Economics, vol. 30, no. 1, pp. 57-79, 2012.

[54] J. Kivilä, M. Martinsuo, and L. Vuorinen, "Sustainable project management through project control in infrastructure projects," International Journal of Project Management, vol. 35, no. 6, pp. 1167-1183, 2017.

[55] A. Mosavi, "Exploring the roles of portfolio steering committees in project portfolio governance," International Journal of Project Management, vol. 32, no. 3, pp. 388-399, 2014.

[56] A. Badewi and E. Shehab, "The impact of organizational project benefits management governance on ERP project success: neo-institutional theory perspective," International Journal of Project Management, vol. 34, no. 3, pp. 412-428, 2016.

[57] S. Pemsel, A. Wiewiora, R. Müller, M. Aubry, and K. Brown, "A conceptualization of knowledge governance in projectbased organizations," International Journal of Project Management, vol. 32, no. 8, pp. 1411-1422, 2014.

[58] R. Joslin and R. Müller, "The relationship between project governance and project success," International Journal of Project Management, vol. 34, no. 4, pp. 613-626, 2016.

[59] A. T. Shiferaw and O. J. Klakegg, "Linking policies to projects: the key to identifying the right public investment projects," Project Management Journal, vol. 43, no. 4, pp. 14-26, 2012.

[60] A. T. Shiferaw, O. J. Klakegg, and T. Haavaldsen, "Governance of public investment projects in Ethiopia," Project Management Journal, vol. 43, no. 4, pp. 52-69, 2012.

[61] A. Khan, "Investigating the practices of project governance in public sector infrastructure program in Pakistan," Advances in Civil Engineering, vol. 2019, Article ID 7436592, 11 pages, 2019.

[62] M. Aubry, M.-C. Richer, and M. Lavoie-Tremblay, "Governance performance in complex environment: the case of a major transformation in a university hospital," International Journal of Project Management, vol. 32, no. 8, pp. 1333-1345, 2014.

[63] T. Tsaturyan and R. Müller, "Integration and governance of multiple project management offices (PMOs) at large organizations," International Journal of Project Management, vol. 33, no. 5, pp. 1098-1110, 2015.

[64] M. Engwall, "No project is an island: linking projects to history and context," Research Policy, vol. 32, no. 5, pp. 789-808, 2003.

[65] R. Miller and B. Hobbs, "Governance regimes for large complex projects," Project Management Journal, vol. 36, no. 3, pp. 42-50, 2005.

[66] S. Pryke and H. Smyth, The Management of Complex Projects: A Relationship Approach, John Wiley \& Sons, Hoboken, NJ, USA, 2012.

[67] R. Müller and M. Martinsuo, "The impact of relational norms on information technology project success and its moderation through project governance," International Journal of Managing Projects in Business, vol. 8, no. 1, pp. 154-176, 2015.

[68] R. Müller, L. Zhai, A. Wang, and J. Shao, "A framework for governance of projects: governmentality, governance structure and projectification," International Journal of Project Management, vol. 34, no. 6, pp. 957-969, 2016.

[69] O. J. Klakegg, T. Williams, and A. T. Shiferaw, "Taming the "trolls": major public projects in the making," International 
Journal of Project Management, vol. 34, no. 2, pp. 282-296, 2016.

[70] C. Benítez-Ávila, A. Hartmann, G. Dewulf, and J. Henseler, "Interplay of relational and contractual governance in publicprivate partnerships: the mediating role of relational norms, trust and partners' contribution," International Journal of Project Management, vol. 36, no. 3, pp. 429-443, 2018.

[71] F. Brahm and J. Tarziján, "Does complexity and prior interactions affect project procurement? Evidence from mining mega-projects," International Journal of Project Management, vol. 33, no. 8, pp. 1851-1862, 2015.

[72] W. J. Henisz, R. E. Levitt, and W. R. Scott, "Toward a unified theory of project governance: economic, sociological and psychological supports for relational contracting," Engineering Project Organization Journal, vol. 2, no. 1-2, pp. 37-55, 2012.

[73] K. Manley and L. Chen, "Collaborative learning to improve the governance and performance of infrastructure projects in the construction sector," Journal of Management in Engineering, vol. 33, no. 5, Article ID 04017030, 2017.

[74] W. Aarseth, T. Ahola, K. Aaltonen, A. Økland, and B. Andersen, "Project sustainability strategies: a systematic literature review," International Journal of Project Management, vol. 35, no. 6, pp. 1071-1083, 2017.

[75] R. Young, M. Young, E. Jordan, and P. O’Connor, "Is strategy being implemented through projects? Contrary evidence from a leader in new public management," International Journal of Project Management, vol. 30, no. 8, pp. 887-900, 2012.

[76] R. Müller and K. Jugdev, "Critical success factors in projects," International Journal of Managing Projects in Business, vol. 5, no. 4, pp. 757-775, 2012.

[77] F. Guo, Y. Chang-Richards, S. Wilkinson, and T. C. Li, "Effects of project governance structures on the management of risks in major infrastructure projects: a comparative analysis," International Journal of Project Management, vol. 32, no. 5, pp. 815-826, 2014.

[78] N. Arranz and J. C. F. De Arroyabe, "Effect of formal contracts, relational norms and trust on performance of joint research and development projects," British Journal of Management, vol. 23, no. 4, pp. 575-588, 2012.

[79] R. Lundin, N. Arvidsson, T. Brady, E. Ekstedt, C. Midler, and J. Sydow, Managing and Working in Project Society: Institutional Challenges of Temporary Organizations, Cambridge University Press, Cambridge, UK, 2015.

[80] T. Brady and A. Davies, "Managing structural and dynamic complexity: a tale of two projects," Project Management Journal, vol. 45, no. 4, pp. 21-38, 2014. 